Received 10 April 2020 Accepted 24 April 2020

Link to DOI:

10.25220/WNJ.V04.S1.0003

Journal Website: www.worldnutrijournal.org

\section{The Overview of Food Technology to Process Soy Protein Isolate and Its Application toward Food Industry}

\author{
Made Astawan ${ }^{1}$, Ayu P.G. Prayudani ${ }^{1}$ \\ 1. Department of Food Science and Technology, Institut Pertanian Bogor, Bogor, West Java, \\ Indonesia
}

\begin{abstract}
Soy protein isolate (SPI) is the purest form of protein from soybean with minimum protein content of $90 \%$. Due to its high protein content, SPI is commonly used in food processing for improving the quality of food products, including infant formula. The use of SPI in infant formula is mainly designed for infant who cannot tolerate cow's milk-based formula. This report reviews the benefit of using SPI in soy-based infant formula rather than soymilk from whole soybean itself. It will also review the technology of soy protein isolation which can result SPI for high quality infant formula, including the reducing of unfavourable ingredients which will ensure the safety of soy protein-based infant formula.
\end{abstract}

Keywords soy protein, soy protein isolate, soy protein based infant formula

\section{Introduction}

Soybeans, which are leguminous crops belonging to the family Fabaceae, have served as a valuable source of food which contain a nutrient source. This plant product has been widely used in a variety of food products. Applications of soybeans in food products are presented in a variety of forms, including infant formulas, cheese, drinks, miso, tempeh, tofu, salami, and vegetarian meat substitutes. ${ }^{1}$

Commonly, soybean derived products, such as soy protein has received growing an attention due to its chemical composition, functional properties, and

\footnotetext{
Corresponding author:

Prof. Dr. Ir. Made Astawan, MS, IPU

Kampus IPB Dramaga, Bogor, West Java 16680, Indonesia

E-mail address: astawan@apps.ipb.ac.id;

mastawan@yahoo.com
}

multiple applications in food industry. According to Codex Standard, ${ }^{2}$ soy protein products are classified based on their dry base protein contents, namely soy flour (40-50\% of protein), soy protein concentrates (70 $-<90 \%$ of protein), and soy protein isolate ( $\geq 90 \%$ of protein).

Each type of soy protein has different application in products according to their functional properties (Table 1). Soy protein has a good supply of essential amino acids compared with other plant proteins. Soy protein has high lysine, which is normally lacking in other cereal, but low in cysteine and methionine. Due to its high protein content $(\sim 90 \%)$, soy protein isolate is considered as one of raw material in producing soy-based infant formula.

\section{Soy Protein Isolate vs Soy Milk}

Soy protein isolate (SPI) is the purest form of protein in soybean with minimum protein content of $90 \%$ (dry basis), which is obtained by extracting the soluble protein and removing non-protein material 
Table 1. Application of soy protein in food products

\begin{tabular}{lcc}
\hline Functional properties & Soy forms & Food Application \\
\hline Fat absorption & F, C, I & $\begin{array}{c}\text { Frankfurters, meat burgers, } \\
\text { sausage, donuts, bologna }\end{array}$ \\
Water absorption & F, C & Confections, breads, cakes \\
Emulsification & F, C, I & $\begin{array}{c}\text { Frankfurters, sausage, bologna, } \\
\text { cakes, and breads }\end{array}$ \\
Solubility & F, C, I & Beverages \\
Gelation & C, I & Meat, curd, cheese \\
Elasticity & I & Baked goods, simulated goods \\
\hline
\end{tabular}

such as fat and carbohydrates. Because of this process, it has a neutral flavour and cause less flatulence than soy flours.

Soymilk is a milky liquid made from whole soybean or full-fat soy flour. Its composition and nutrient are similar to those of dairy milk. ${ }^{4}$ Soymilk processing is including soaking soybean in water, filtering the soybean slurry with gauze, and heating the obtained filtrate by sterilization. According to its processing, it showed that soy milk still contains more non-protein content compared to SPI.

Furthermore, SPI has higher Protein Digestibility Corrected Amino Acid Score (PDCAAS) compared to soymilk, which is $100 \%$ and $92.6 \%$ respectively. ${ }^{5}$ It shows that PDCAAS of SPI is equivalent to animal proteins quality, suggested that SPI is essential as alternative protein source to support growth of infant.

Infant formula is designed to be a supplement to breast milk, and may be also used as a substitute if breastfeeding is feasible, which is made by mixing proteins, fats, carbohydrates, minerals, and vitamin components. The mixture is then blended, pasteurized, homogenized, and condensed, then either spray-dried (powder-base) or sterilized (drink-base). ${ }^{6}$

Soy-based infant formula is designed as a suitable alternative for infant with intolerance to lactose and cow's milk proteins. Lactose intolerance occurs when small intestine fails to produce sufficient amount of lactase enzyme. Lactase enzyme is released in normal infant's digestive system in order to digest milk, including breast milk, whether premature infants sometimes fail to produce enough lactase. ${ }^{7}$

\section{Benefit Use of SPI in Market}

Soy protein products, especially SPI have been used as food ingredients in wide category due to their nutritional and functional properties. Moreover, soybean is a low-cost vegetable sources of protein, which cause soy protein products offer more than just obvious economic advantages that vegetable proteins have over animal proteins. Soybean processing into soy protein has resulted in products that can be used for many functions in foods, such as emulsification, binding, and texture. ${ }^{8}$ The excellent nutritional value of soy protein has been recognized by Food and Drug Administration (FDA) and the United States Department of Agriculture's (USDA) School Lunch Program.

One of SPI use in the market is as the protein main source in infant formula. Soy-protein based infant formulas in the United States are nearly $25 \%$ of the formula market, $13 \%$ in New Zealand, $7 \%$ in the United Kingdom, $5 \%$ in Italy, and 2\% in France, which use SPI as their main ingredients. ${ }^{9,10}$ In the beginning of their launching into the U.S. market in 1950, soy-based infant formulas were using soy flour as their raw material. The formulas were tan in color and had a nutty odor. Then, in the 1960 s, soybased infant formulas came up with SPI, and within 10 years almost completely replaced soy flour-based infant formula in the U.S. Those formulas are only 
darker than milk-based formulas and nearly odourless. $^{11}$

Not only benefit for their appearance, SPI also have lower phytate content because of precipitation method in obtaining protein isolates. The method resulting the increase of absorption and availability of zinc and copper in infant rhesus monkeys and rat pups due to the reduction of the phytate content of soy formula by using SPI. ${ }^{12}$

\section{Food Technology of SPI and Impact on Unfavourable Ingredient}

The general methods of soy protein isolation are using aqueous extraction process (isoelectric precipitation principal) and membrane ultrafiltration process. Aqueous extraction technique is based on the solubility of protein at different pHs. Basically, SPI are produced by extracting the soy flakes in alkali condition ( $\mathrm{pH} 8-9)$ with subsequent centrifugation to produce a soy protein extract containing soluble protein, oligosaccharides, and minerals. Acidification of the obtained extract to $\mathrm{pH}$ 4.5 (isoelectric point) will precipitate the proteins into a curd. Subsequent washing of the curd will remove soluble non-protein component. The following neutralization at $\mathrm{pH} 7$ and drying finally will result $\mathrm{SPI}^{3}$.

Whether ultrafiltration membrane is using membrane isolation technique. Different from aqueous extraction, membrane isolation recovers protein directly from soybean flour extracts and thus avoid the generation of whey protein from acidprecipitation, which results higher protein isolate yield, since one-third of soy whey proteins are very hard to recover. ${ }^{13}$ According to Codex Standard, ${ }^{2}$ maximum water content, ash content, and crude fiber of SPI is 10,8 , and $0.05 \%$ respectively, with minimum protein content of $90 \%$.

Soybeans naturally had anti-nutritional factors such as phytic acid, trypsin and other enzyme inhibitors, lectin, and phenolic compounds, which can cause undesirable effects on digestion and absorption of nutrition. Results found that SPI with ultrafiltration process had low phytic acid content, improved digestibility, high water solubility, improved functional properties, and absence of beany flavour with high palatability and nutrition due to the removal of oligosaccharides and minerals which are permeate through the membrane. ${ }^{14}$

Removal of phytic acid in SPI can improve digestibility of minerals such as calcium, therefore manufactures do not need to enrich their soymilk products with calcium carbonate to ensure adequate adsorption. Soybean also contains isoflavones (phytoestrogen) which have been of particular interest due to their effects on sexual development and reproduction. Approximately, $30 \%$ of the total isoflavones are lost in the insoluble fraction during SPI production. ${ }^{15}$ Another study also showed that soymilk which was made from SPI had lower isoflavones content compared to soymilk from whole soybean due to loss of isoflavones occurs during the separation of isolated protein. ${ }^{16}$

Numerous studies showed that dietary isoflavones in soy-based infant formula do not adversely affect human growth, development, or reproduction. ${ }^{17}$ Setchell et al. ${ }^{18}$ reported that no clinical symptoms, growth, or development adverse effects related to plasma concentration of isoflavones in soy-fed infants. Furthermore, there was also no reported adverse estrogenic effects on sexual development in infants fed soy-based infant formula.

Businco et al. ${ }^{19}$ also reported that phytoestrogens in soy-based infant formula did not induce hormonal effects in 34 young adults who had been fed soy-based infant formula when they were toddlers. Strom et al. ${ }^{20}$ also found no statistically significant differences in general health and development between groups who had soy-based infant formula and groups who had milk-based infant formula during their first 4 months, in either females or males. It showed that sexual development and maturation of infants fed soy-based infant formula are normal.

Soymilk has not gained popularity compared to cow's milk due to its off-flavour and only used as a milk substitute by a group of people who cannot tolerate cow's milk. The off-flavour (beany/grassy, bitter, and astringent flavour) of soymilk was from soybean, which was as a result of lipid oxidation, lipoxygenase activity, polar lipids, bitter peptide and lipids ${ }^{21}$. Soybean defatting and protein extraction could have a significant impact on the taste and flavour of SPI and thus on the finished food products 
due to the removal of lipids in soy flakes which are the major substrate of lipoxygenase . $^{3}$.

Besides, the presence of allergenicity in SPI could be removed by using HHP (High Hydrostatic Pressure) processing. HHP treatment could significantly influence the free SH (Sulfhydryl) content and hydrophobicity of SPI, which are closely associated with the allergenicity of SPI. HHP would influence that interaction and interfere with the structure of soy allergen epitopes, thus reducing the allergenicity of SPI. HHP treatment at $300 \mathrm{MPa}$ and 15 min could decrease allergenicity up to $48.6 \%$ compared to native SPI. ${ }^{22}$

\section{Food Processing to Ensure High Quality of SPI Formula for Children}

Infant formula is designed for use as a substitute for human milk when breastfeeding is unable, then there should be a processing technology to achieve nutrient similarity to human milk. Ingredients added to soy-based infant formula are SPI, which utilize as the main protein source, and supplemented with Lmethionine, carnitine, and taurine.

SPI is added to achieve protein content ranging 2.45-2.8 g per $100 \mathrm{kcal}$. Besides, soy-based infant formula does not contain lactose, it needs addition of corn maltodextrin, corn syrup solids, and sucrose as replacers for carbohydrates then to provide carbohydrate content of 10.26-10.95 g per $100 \mathrm{kcal}^{23,9}$ Furthermore, addition of lipids is also needed, which content ranges from 5.02-5.46 g per $100 \mathrm{kcal}$, since lipids are predominant source of energy, required for absorption of fat-soluble vitamins, carotenoids, cholesterol, and contribute to flavours and satiety. Fat blends of soy oil and coconut oil with proportions $40 \%$ and $60 \%$ respectively, which have higher absorption of fat and mineral compared to mixture of palm oil and soy oil.

Soy-based infant formula also needs to be fortified with iron as a way of reducing the prevalence of anemia. Moreover, vitamin such as vitamin D3, vitamin $\mathrm{K}$, vitamin B12 also found in many fortified infant formula. ${ }^{9,24}$

Infant formulas are commonly sold in powdered form. Powdered infant formula is generally manufactured using one of two types of process, namely dry blending process or wet mixing- spray drying. Briefly, dry blending process is process of combining all of the dry ingredients which previously have been prepared individually (heat-treated) to finally dry-blended, whether wet mixing-spray process is using all ingredients in a liquid phase and heat-treating (pasteurization/sterilization) to finally dry-sprayed. Each process has its own advantages and disadvantages.

The advantages of using the dry blending process are using less energy and having the less risk of microbiological contamination because the water is not involved in this process, but the disadvantages are no heat treatment to destroy bacteria in the final product. Furthermore, the different ingredients will segregate during transportation and storage due to their varied densities, resulting in inhomogeneous state for the consumer. ${ }^{25}$

The wet mixing-spray process currently remains the most widely used method of producing powdered infant formula. ${ }^{23}$ The advantage of this process is all quality aspects can be more effectively controlled than dry mixing process, resulting improved quality powder including microbiological, physical, and chemical properties, whether its disadvantage is using more energy and time compared to dry mixing process. ${ }^{25}$

\section{Concern of GM and Non-GM Soybean}

Genetically-modified (GM) organisms are crop plants that using the latest molecular biology techniques and have been modified to enhance some desired traits. Soybean is one of the examples of GMO results. This kind of soybeans is herbicide Roundup ${ }^{\circledR}$ (glyphosate)-resistant, that will reduce the production cost and limit the dangers of agricultural waste run-off.

In the U.S., the cultivation of GM soybeans was increasing every year. In 1996, approximately $7 \%$ of all soybeans cultivated were GMO, up to $42 \%$ in 1998 , and increased to $54 \%$ of all soybeans in $2000 .{ }^{26}$ But, GMO still has concerns related to human health risks and long-term effects on human beings. Many people prefer to stay away from GMO because of the transfer of antibiotic resistance, toxicity, and allergenicity possibility due to the presence of transgenes that have been inserted into the crops. Because of these issues, labelling of GM 
foods is required by EU legislation, as a tool for the first-time consumer to get well-informed. ${ }^{27}$ However, several studies showed no meaningful effects and differences from GM soybeans compared to non-GM soybeans. Netherwood et al. ${ }^{28}$ reported no gene transfer occur during GM soy fed in seven human volunteers' gut because the transgene did not survive passage through intact gastrointestinal tract.

Another study also found no biologically significant differences occur in the in vivo nutritional response of body weight, body weight gain, and food consumption of rats compared to the non-GM soybeans in the diet. That indicate both soybeans were nutritionally equivalent, providing evidence that GM soybeans did not have cause unintended deleterious nutritional changes. Furthermore, no significant differences in MDA (Malondialdehyde) and PC (Protein Carbonyl) levels of rats were found, indicate no differences in lipid peroxidation and protein oxidation levels. ${ }^{29,30}$

\section{Conclusion}

Soy protein isolate (SPI) has been widely used due to its chemical composition, functional properties, and multiple applications in food industry, including soy-based infant formula, which is mainly designed for infant who cannot tolerate cow's milk-based formula. The use of SPI can be beneficial for infant formula by resulting better appearance and flavor, lower phytate content, higher protein digestibility, and higher mineral absorption and availability due to protein isolation process with ultrafiltration method, compared to soy-based infant formula using soybean itself. Furthermore, presence of allergenicity in SPI also could be removed by using HHP (High Hydrostatic Pressure) processing. Several studies related to particular interests in soybean such as isoflavone and GMO issues also reported no meaningful adverse effects, which indicate SPI is safe for used as raw material for infant formula production.

\section{Conflict of Interest}

Authors declared no conflict of interest regarding this article.

\section{Open Access}

This article is distributed under the terms of the Creative Commons Attribution 4.0 International Licence

(http://creativecommons.org/licenses/by/4.0/), which permits unrestricted use, distribution, and reproduction in any medium, provided you give appropriate credit to the original author(s) and the source, provide a link to the Creative Commons license, and indicate if changes were made.

\section{Reference}

1. Sacks FM, Lichtenstein A, Van Horn L, Harris W, Kris-Etherton P, Winston M. Soy protein, isoflavones, and cardiovascular health: an American Heart Association Science Advisory for professionals from the Nutrition Committee. Circulation. 2006; 113(7): 1034-44.

2. [CAC] Codex Alimentarius Comission. Codex General Standard for Soy Protein Products. Roma: Food and Agriculture Organization of the United Nations World Health Organization; 1989.

3. Ma Z. Chapter 2: Soy Protein: Research Advances on The Relationships among The Processing Techniques, Nutritional Quality, Functional Properties, and Application in Various Food Products. In: Casamides J, Gonzalez H, editors. Soy Protein: Production Methods, Functional Properties, and Food Sources. New York: Nova Science Publishers; 2014. p. 47-76.

4. Odo T. Soy (Soya) milk. Encyclopedia of Food Sciences and Nutrition; 2003. p. 5403-06.

5. Sarwar G. The protein digestibility-corrected amino acid score method overestimates quality of proteins containing antinutritional factors and of poorly digestible proteins supplemented with limiting amino acids in rats. J Nutr. 1997; 127(5): 758-64.

6. Hendricks GM, Guo M. Chapter 9: Component Interactions and Processing Damage during the Manufacture of Infant Formula. In: Guo M, editor. Human Milk Biochemistry and Infant Formula Manufacturing Technology. Cambridge: Woodhead Publishing; 2014. p. 233-45.

7. Genauer $\mathrm{CH}$, Hammer HF. Chapter 101: Maldigestion and malabsorption. In: Feldman M, Friedman LS, Sleisenger MH, editors. Sleisenger \& Fordtran's Gastrointestinal and Liver Disease. 9th edition. Philadelphia: Saunders Elsevier; 2010.

8. Endres JG. Soy Protein Products: Characteristic, Nutritional Aspects, and Utilization. Champaign: AOCS Press; 2001. 
9. Bhatia J, Greer F. Use of soy protein-based formulas in infant feeding. Pediatrics. 2008; 121(5): 1062-68.

10. Agostoni C, Axelsson I, Goulet O, Koletzko B, Michaelsen KF, Puntis J, et al. Soy protein infant formulae and follow-on formulae: a commentary by the ESPGHAN Committee on Nutrition. Pediatr Gastroenterol Hepatol Nutr. 2006; 42(4): 352-61.

11. Fomon JS, Ziegler EE. Isolated soy protein in infant feeding. Boca Raton: CRC Press; 1992. p. 75-83.

12. Lonnerdal BO, Jayawickrama L, Lien EL. Effect of reducing the phytate content and of partially hydrolyzing the protein in soy formula on zinc and copper absorption and status in infant rhesus monkeys and rat pups. Am J Clin Nutr. 1999; 69: 490 Y6.

13. Alibhai Z, Mondor M, Moresoli C, Ippersiel D, Lamarche F. Production of soy protein concentrates/isolates: traditional and membrane technologies. Desalination. 2006; 191(1-3): 35158.

14. Goodnight Jr KC, Hartman Jr GH, Marquardt RF. Aqueous Purified Soy Protein and Beverage. US Patent 3995071; 1976.

15. Rickert DA, Johnson LA, Murphy PA. Improved fractionation of glycinin and $\beta$-conglycinin and partitioning of phytochemicals. J Agric Food Chem. 2004; 52(6): 1726-34.

16. Setchell KDR, Cole J. Variations in isoflavone levels in soy foods and soy protein isolates and issues related to isoflavone databases and food labeling. J Agric Food Chem. 2003; 51(14): 414655.

17. Merritt RJ, Jenks BH. Safety of soy-based infant formulas containing isoflavones: the clinical evidence. The Journal of nutrition. 2004; 134(5): 1220S-4S.

18. Setchell KD, Zimmer-Nechemias L, Cai J, Heubi JE. Isoflavone content of infant formulas and the metabolic fate of these phytoestrogens in early life. Am J Clin Nutr. 1998; 68: 1453S-61S.

19. Businco L, Bruno G, Giampietro PG, Furcolo G. No oestrogens hormonal effects in long-term soy formula fed children. J. Allergy Clin. Immunol. 1999; 103: S169.

20. Strom BL, Schinnar R, Ziegler EE, Barnhart KT, Sammel MD, Macones GA, et al. Exposure to soybased formula in infancy and endocrinological and reproductive outcomes in young adulthood. J. Am. Med. Assoc. 2001; 286: 807-14.

21. Li R. Soy product off-flavor generating, masking, and flavor creating. Boca Raton: Taylor \& Francis; 2006.

22. Li H, Zhu K, Zhou H, Peng W. Effects of high hydrostatic pressure treatment on allergenicity and structural properties of soybean protein isolate for infant formula. Food Chem. 2012; 132(2):808-814.

23. Montagne D., Van Dael P, Skanderby M, Hugelshofer W. Chapter 9: Infant formulaepowders and liquids. In: Tamime AY, editor. Dairy powders and concentrated products. Westmorland: Wiley Blackwell; 2009. p. 294-331.

24. Guo M, Ahmad S. Chapter 7: Ingredients selection for infant formula. In: Guo M, editor. Human Milk Biochemistry and Infant Formula Manufacturing Technology. Cambridge: Woodhead Publishing; 2014. p. 172-210.

25. Jiang YJ, Guo M. Chapter 8: Processing technology for infant formula. In: Guo M, editor. Human milk biochemistry and infant formula manufacturing technology. Cambridge: Woodhead Publishing; 2014. p. 211-29.

26. Whitman DB. Genetically modified foods: harmful or helpful ?. CSA Discovery guides. 2000. p 1-13.

27. Bawa AS, Anilakumar KR. Genetically modified foods: safety, risks and public concerns - a review. Int J Food Sci Tech. 2013; 50(6): 1035-46.

28. Netherwood T, Martín-Orúe SM, O'Donnell AG, Gockling S, Graham J, Mathers JC, et al. Assessing the survival of transgenic plant DNA in the human gastrointestinal tract. Nat Biotechnol. 2004; 22(2): 204-9.

29. Sbruzzi FA, Venâncio VDP, Resck MCC, Brigagão MRPL, Azevedo L. Transgenic and conventional Brazilian soybeans don't cause or prevent preneoplastic colon lesions or oxidative stress in a 90-day in vivo study. Rev Nutr. 2013; 26(4): 44353.

30. Venâncio VP, Silva JPL, Almeida AA, Brigagão MR, Azevedo L. Conventional (MG-BR46 Conquista) and transgenic (BRS Valiosa RR) soybeans have no mutagenic effects and may protect against induced-DNA damage in vivo. Nutr Cancer. 2012; 64(5): 725-31. 